\title{
Reincarnation of winds of change in Africa: an African Union impotence?
}

\author{
EPABABIO
}

\begin{abstract}
The emergence of African states as independent by 1970 had brought hope and expectations to nationals that the winds of change were to be equated with good life and freedom. Yet, no sooner had political freedom been gained than expectations turned elusive. The causes were bad political governance that soon burdened many states, military interventions of one-party states, abuse of rule of law, mass corruption and nations disintegrating. Also, the quest for freedom and dignity was not helped by a continental union that focused solely on political liberation of Africa and ignored any concerted effort towards integration and promotion of socio-economic lives of people.

This article examines the political tremors that had engulfed some states in Africa and the resultant intervention by foreign powers. It is argued, that a major cause of the political ruffle in Tunisia, the Cote D'Ivoire, Egypt and Libya had been the inability of the African Union to be pro-active in enforcing norms of good governance among member-states through its inspecting agency, the African Peer Review. The apparent political paralysis is therefore a function of an African Union impotence that needs to be resolved Underlying the tremors are issues of democracy, good governance, and public service reform for which a theoretical discourse is engaged.
\end{abstract}

Key words: African Union, democracy, governance, revolution, impotence. APRM, civil war

Disciplines: Public Management, African Studies, Political Studies

\section{Introduction}

In 1960, no less than 22 African states were granted independence by the British and French colonial masters. This sweeping event prompted the then British Prime Minister, Harold McMillan to warn the then apartheid South African government, in a scathing speech in Parliament in Cape Town, with the euphemistic expression, "the winds of change" are sweeping across Africa.

The winds of change, together with the political thoughts of Pan Africanists Kwame Nkrumah, Modibo Keita, Nnamdi Azikiwe, and Haile Sellasie, amongst others, precipitated

1. Professor Ernest P Ababio, is the subject head for Public Management and Administration, NorthWest University (Vaal), Ernest.Ababio@nwu.ac.za 
the founding of the continental union, the Organization of African Unity (OAU) in May 1963. The prime objective of the OAU was the political liberation of Africa, an objective that ignored any concerted effort towards nation-building and promotion of socio-economic lives of Africans. Sixty years after Harold McMillan, winds of change have resurfaced in Africa, not against former colonial bourgeoisie, but in different forms namely, popular uprising by the mass to overthrow despotic leaders. At the heart of the reincarnation of the winds of change are issues of democracy and governance.

\section{Democracy and governance}

Democracy as a concept appears elusive in definition, yet specific issues that the concept embodies can be identified. Tenets of a developed, democratic state involve the existence of a system with freedom of speech, freedom of association and assembly, as is the right to stand for office, a free press and a secret ballot. Further, these tenets are strengthened by the presence of a credible opposition, pluralism based on a strong civil society, a strong economy, and a distinction between the State and the ruling party (Thomson, 2000: 216-218). Such tenets as outlined are a function of good governance which is equally a multi-faceted concept outlined as follows (Maserumule 2005: 194-212):

- The act or manner of governing, of exercising control or authority over the actions of subjects;

- The use of political authority and exercise of control in society in relation to the management of resources for social and economic development;

- The use of political, economic and administrative authority and resources to manage affairs of a nation; and

- The acquisition of and accountability for the application of political authority to the direction of public affairs and management of public resources.

Currently the concept good governance has become very popular and its definition varies from one organisation (or people) to the other (Agere 2000: 3). Good governance is a social management process, which could maximise the public interest, that is, what policies improve majority of the populace (Hanekom, 1987: 53). The substantive characteristic of good governance is that it is a co-management of public life operated by both government and citizens, and establishes a new relationship between government and civil society (Yuanfang et al 2009: 1) For the purpose of this article governance is seen as the acquisition of political power by a political party through democratic process and the judicious allocation of resources for the improved well-being of a citizenry. The lack of these governance ingredients, which the AU has not been able to pro-actively promote, is the heart of the reincarnated winds of change in some African states.

Achieving these democratic tenets in developing states is a function of public service reform, which is the reason for the establishment of the African Peer Review Mechanism (APRM). Yet, almost a decade after its inception, Graca Machel, a prominent member of the APRM, laments the "worrisome trend of coups d'état and post-election conflicts in Africa" (Machel 2009: 10). These, together with issues such as limited membership, tend to prompt the question: The APRM process - quo vadis? It is argued that the APRM is Africa's trump card for public service reform, yet, as will be explained later, its effectiveness varies positively with restructure in membership and of the APRM itself. 


\section{The concept of public service reform}

Public service reform as a concept may be seen as "a change in the direction of greater economic or political equality, and a broadening of participation in society and policy.", And, in addition, as "the devolution of responsibilities away from centralized bureaucracy" (Huttington, in Kuye, 2006: 291). A common theme in these definitions is that a process of public service reform has as its objective the involvement of civil society in the art of government, and the enhancement of service delivery through devolution and decentralization. Such is the summary of the mission of the APRM. Analysis of the concept public service reform would involve the following functions, amongst others (Mutahaba 2006: 274):

- Restructuring and rationalisation of government operations.

- Control of employment and size of the public service.

- Good governance.

- Decentralisation and local government.

- Privatization and private sector development.

- Legal/judicial service reform.

- Reforms related to improving performance of specific sectors

\section{The African peer review mechanism}

Peer review refers to the systematic examination and assessment of the performance of a State by other states (peers), by designated institutions, or by a combination of states and designated institutions. Thus, a number of intergovernmental and international organizations such as the European Union, UN bodies and the IMF use peer review to monitor and assess national policies and performance in several sectors (Hope, 2005: 290). In academia, peer review is undertaken when an editor of academic repute makes an initial assessment of the suitability of a paper for a journal and then sends it to a number of referees to adjudicate suitability for publication (Kanbur, 2004: 158). The peer review process of Africa, however, is largely political in that it covers the entire fabric of the functioning of governments.

The African Peer Review Mechanism (APRM) is an African-led innovation that represents a bold approach to reform for building capable states with enduring good governance and sustainable development. The APRM is designed to monitor and assess progress made by African countries in meeting their commitment toward achieving good governance, social reforms and sustainable development (Hope, 2005: 289). It is an instrument voluntarily acceded to by member states of the African Union as an African self-monitoring mechanism (though the voluntary membership notion is a weakness of the process). The mandate of the APRM is to ensure that the policies and practices of participating states conform to the agreed political, economic and corporate governance values, codes and standards contained in a Declaration on Democracy, Political, Economic and Corporate Governance (Hope, 2005: 289).

\section{Structural Functioning of the APRM}

The overall responsibility for the APRM lies with the Committee of Participating Heads of State and Government of the Member States of the APRM, titled the APR Forum. The mandates of the APR Forum are, amongst others (www.nepad.org), 
- appointing the APR Panel of Eminent Persons, considering the country review reports, making appropriate recommendations to the reviewed countries and exercising constructive peer dialogue and persuasion;

- ensuring that the APR process is fully funded; and

- persuading development partners to provide technical and financial assistance to support the implementation of the programme of action of the reviewed countries.

A further constructive process of engaging Africa involves the composition of the review panel. A Panel of Eminent Persons (APR Panel) depicting regional and gender diversity is appointed by the heads of state to oversee the APRM process and ensure its integrity. The APR Secretariat, which provides the secretarial, technical, co-ordinating and administrative support services for the APRM assist the APR Panel. The APRM Secretariat is currently housed in the secretariat of the New Partnership for Africa's Development (NEPAD) in Midrand, South Africa.

The candidature of an APR Panel member is dependent on criteria such as Africans who have distinguished themselves in careers considered relevant to the work of the APRM, namely expertise in the areas of political governance, macro-economic management, public financial management and corporate governance. Further, appointees should be persons of high moral stature and with demonstrated commitment to the ideals of Pan Africanism. Thus, quality in candidature provides a strong basis for the APRM process. Candidates for appointment are nominated by participating countries, short-listed by a Committee of Ministers and appointed by heads of state and governments of participating countries.

The modus operandi of the APRM serves as a further strong need of the process. The panel exercises oversight functions over the review process, in particular to ensure the integrity of the process. The APR Charter secures the independence, objectivity and integrity of the panel. The panel is supported by a competent secretariat that has the technical capacity to undertake the analytical work that underpins the peer review process and conforms to the principles of the APRM. The functions of the secretariat include maintenance of extensive database information on political and economic developments in all participating countries, preparation of background documents for the peer review teams, proposing performance indicators and tracking performance of individual countries (www.nepad.org).

Participation in the APRM is voluntary and open to all member states of the African Union. As pointed out by Kuye (2006: 292), voluntary participation departs from the principle of sovereignty of states and recognizes that a State cannot be compelled to follow any prescribed model of governance. Instead, the APRM seeks to help willing countries improve governance as a precondition for integration and development, and acknowledges that each country is unique in terms of the socio-political, economic and cultural environment and that these selfcharacteristics should inform recommendations for improvement. What makes engagement by APRM quite constructive is that the mechanism of peer review is a non-adversarial and non-punitive process in which trust among participating countries is crucial for its success.

The argument for voluntary participation is an anomaly. Invariably the decision not to belong to the APRM process is a prerogative of a small elite of political bureaux in states whose agenda is the continued maintenance of policies that oppress the wider mass. It is submitted that states that belong to a common Union must be reviewed under a common denominator. Currently, thirty one countries have acceded by signing the Memorandum of Understanding. These are Algeria, Angola, Benin, Burkina Faso, Cameroon, Djibouti, the Republic of the Congo, Egypt, Ethiopia, Equatorial Guinea Gabon, Mali, Mauritania, Mauritius, Senegal, 
Tanzania, Lesotho, Sierra Leone, Malawi, Ghana, Kenya, Liberia Mozambique, Nigeria, Rwanda, Sao Tome \& Principe, Togo, South Africa, Sudan, Uganda and Zambia. Thus, as a clear departure from the mood and position of non-interference in 2000, about half of the African states sincerely open their governance systems for constructive territorial review.

\section{Matrix for promoting public service reforms}

The APRM process involves scientifically worked-out objectives and stages. At the time of acceding to the peer review process, each State should clearly define a time-bound programme of action for implementing the Declaration on Democracy, Political, Economic and Corporate Governance, including periodic reviews. To facilitate the process, it has become a norm for reviewing a State to designate or create an institution as focal point for review. Thus, Ghana created a new Ministry of Regional Co-operation and NEPAD, with former Minister KK Apraku in charge, and in South Africa, the then President allocated Minister Geraldine Fraser-Moleketi of Public Service and Administration with the coordinating responsibility for the APRM process (www.aprm.org.za). In an attempt to facilitate public service reform, the APR process involves four types of reviews (www.nepad.org):

- The base review carried out within eighteen months of a country becoming a member of the APRM process;

- A periodic review takes place every two to four years;

- For its own reasons, a member country can ask for a review that is not part of the periodically mandated reviews; and

- Early signs of an impending political or economic crisis in a member country would also be sufficient cause for instituting a review. Such a review can be called by participating heads of state and government "in a spirit of helpfulness" to the government concerned.

The APR process involves specific stages. Stage one entails a study of the political, economic and corporate governance and development environment in the country for review. The study is based on current documentation prepared by the APRM Secretariat and material provided by national and international institutions. In Stage two, the Review Team visits the country concerned to carry out the widest range of consultation with the government, officials, political parties, parliamentarians and representatives of civil society organizations including the media, academia, trade unions, business and professional bodies. In Stage three, the team prepares its report, which is based on information from the secretariat and the consultation briefings held. The report is first given to the government for comment, giving it the opportunity to decide how the identified shortcomings may be addressed. Stage four begins when the APRM Secretariat submits the team's report to the participating heads of state and government. After the fourth stage, participating heads continue to engage the reviewed State by means of assistance in the form of dialogue, technical advice and a collective intention to proceed with appropriate measures by a given date. Six months after the report has been considered by participating heads of state and government, the report is tabled in key regional structures such as the Pan African Parliament and the Peace and Security Council. This constitutes the fifth and final stage of the process. 
Specific public service reforms

In engaging a process of public service reform in Africa, commonalities exist in states. Further, a primary element of good governance that needs reform in Africa is ensuring that citizens have a say in how they are governed (Kuye, 2006: 291). Consequently, Mutahaba (2006:274) outlines the following commonalities for reform:

- Re-examination of the role of government, that is. what government should do and not do.

- Re-examination of the costs of running business of government

- Decentralisation and devolution of authority within a government.

- Consideration of more cost-effective ways of service delivery, including privatisation or corporatisation of activities.

- Partnership between the government and the private sector in providing services.

The specific reforms that mark the peer review agenda follow key objectives in regard to, as outlined above.

The key objective of the APRM process is to identify the extent of development or weaknesses in specific public service functions in the context of the four peer review areas. The key objectives for democracy and political governance, as rightly observed by Maloka (2004: 10), draws strongly from the declaration on unconstitutional changes of government. The objectives are (www.aprm.org.za):

- To prevent and reduce conflict within and between countries;

- The consolidation of constitutional democracy that includes periodic political competition, the rule of law and the supremacy of the firm establishment of the constitution

- Upholding tenets of separation of powers including the protection of the independence of the judiciary and of an effective parliament;

- Ensuring accountable, efficient and effective public office holders and civil servants;

- Fighting corruption in the political arena; and

- Promotion and protection of the rights of vulnerable groups including women, children, the disabled and displaced persons.

The above are essentially quality indices that promote democracy, accountability and, ultimately, good governance.

The key objectives for economic governance and management include

- Promoting macroeconomic policies that support sustainable development;

- Implementing transparent, predictable and credible government economic policies;

- Promoting sound public finance management;

- Fighting corruption and money laundering; and

- Accelerating regional integration by participating in harmonization of monetary, trade and investment policies among participating states.

As was pointed out earlier, a major factor in promoting and sustaining democracy is existence of a strong economy. The above objectives of the APRM are, therefore meant to fulfil that tenet and, by implication, as a way of promoting political stability in African states.

Equally laudable key objectives are outlined in the key areas of corporate governance and socioeconomic development. Thus far, the matrix has been used to review seven states, 
namely Ghana, Rwanda, Kenya, South Africa, Algeria, Benin and Uganda (www.aprmdocuments)

\section{The winds of change}

Between December 2010 and September 2011, there had been political crises in some African states mentioned earlier that had been engulfed in political rioting that led to regime change in respective states. Such has been the case in Tunisia, Cote D'Ivoire, Egypt and in Libya. The irony of governance is that in all these crises, resolution was by foreign power intervention, a situation which contradicts the Charter of the AU to resolve crises in Africa by Africans and which has exposed authority of the AU to impotence.

The Tunisian revolution was an intensive campaign of civil resistance that began in December 2010 and led to the ousting of long time President Zine El Abidine Ben Ali in January 2011. The demonstrations were precipitated by high unemployment, food inflation, corruption, a lack of freedom of speech and poor living conditions (Cole 2011: 15) These give credence to the absence of democratic values espoused earlier and which could have been prevented had Tunisia gone through the APRM process.

The Ivorian crises began after incumbent President Laurent Gbagbo claimed he had won elections, the first in 10 years! The opposition candidate, Alassane Ouattara, and a number of countries, organizations and leaders worldwide claimed that Ouattara had won. After hectic violence and deaths, the AU appointed former South African President Thabo Mbeki on 5 December 2010 as mediator. Mbeki left the following day without a deal On 11 April 2011, Gbagbo was captured by pro-Ouattara forces, backed by French troops! (Cohen, 2011: 1-16)

The Egyptian revolution began on 25 January 2011 and continued in the year. Grievances of Egyptian protesters focused on governance issues of legal and political matters namely: police brutality, state of emergency laws, lack of free elections and freedom of speech, uncontrollable corruption, high unemployment, food price inflation, and an end to the regime of Hosni Mubarak who had ruled Egypt since 1981! (Ashton, 2011: 1-41). Like the Tunisian crises, the Egyptian revolt borders on issues of governance, which could have been pre-empted by a review by the APRM.

The Libyan civil war from 15 February marks a test of paralysis or strength of the AU. President Muammar Gaddafi had been the ruler of Libya since 1969, when he led a military coup that overthrew King Idris 1. Gaddafi's governance style was nepotism, placing relatives and loyal tribe members in central military and government positions. Despite a per capita income of $\$ 14878,21 \%$ of Libyans were unemployed; and one-third lived below poverty line. The popularity of the mass uprising had been demonstrated by its composition namely: teachers, students, lawyers, oil workers and a contingent of professional soldiers that defected from the Libyan army ( Lamb, 2011: 57-73).

Intervention in the Libyan crisis for resolution had been by heavy foreign presence: of UN Security Council resolutions, of NATO operations by the USA, French, Norway and Italian bombings, and of the Arab League suspension of Libya for crimes against popular protesters. On the contrary, AU intervention had been insignificant namely, of despatching President Zuma of South Africa to arrange a ceasefire (which didn't materialise) and by constructed a veiled roadmap which had no impact, and which had to be amended to recognize the interim government of the protesters (Rossouw 2011: 16). 
Wither thou, the peer review process then?

The catalogue of events outlined by the winds of change urgently requires that the AU transform its agenda on issues of governance in Africa by empowering the APRM. Given the international experience with peer reviews, the APRM has the potential to provide a number of benefits to reviewed states (Hope, 2005: 295). As African countries seek to improve their governance through public service reforms, the APRM provides the basis for policy changes to meet commitments and to observe the agreed upon standards and codes. The process facilitates the monitoring of compliance with agreements entered into, and states are much more inclined to comply within oversight functions of the APRM. African political history is replete with corruption and resultant disastrous effects of bad governance that precipitated coups d'état in states like Ghana, Nigeria and Togo Given such historical record, the review process represents a change in the thinking of African leaders and a major milestone in the political development of the continent. The South African Government adds that the APRM country review will enhance efforts by South Africa to meet challenges of the next decade, help build institutions involved in the promotion of democracy and relationships between these institutions and individuals, help address the challenges raised by the second economy and will help South Africa's efforts in job creation and improved service areas such as health, education, housing and other basic services (www.aprm.org.za). In addition, the peer review process lends credibility to Africa at a time of growing donor dryness and deep external cynicism. More crucially, the APRM represents the legitimization of a reform process that wards off the external pressure that is usually associated with imposed conditions from external lending institutions (Juma, 2004:178).

\section{An African Union impotence?}

A number of factors tend to reduce the authority of the African Union as a continental body. The issue of voluntary membership of the APRM stands tallest.

.Years after its inception, membership of the APRM comprises a meagre 55 per cent of African states. Thus, while good governance is being relatively promoted in participating states, political and economic turmoil are potential in 45 per cent of the states. Worse still is that a number of non-member states have authoritarian or totalitarian systems such as it was in Libya. It was even more ironic that in 2009 the chair of the AU, namely Libya, was a nonmember, a situation that undermines the legitimacy and credibility of the process. This is an anomaly that suggests that membership of the APRM process can no longer be voluntary.

The potential of the AU to take charge of its affairs is constrained by financial incapacity as exposed by the following scenario (Maru 2011: 12)

- The EU, together with China and the USA are to contribute over R1billion to the AU budget of 2011.

- Germany is to fund a new building for the Peace and Security Council in Addis Ababa for R100million.

- Libya paid the dues of states like Niger and Togo; and often hosted the second AU summit for the year, and wanted the AU to formalise that tradition.

- As pointed out by Le Roux (2009:25) the impotence of the AU is further exposed by Libya's hand in oil production in several African states which gave Libya virtual management control of the states. 
The process for engagement needs further attention. Currently, engagement by the Forum of Participating Heads of State with a reviewed state occurs only at the fourth stage of the process. Yet, political flashpoints abound in Africa, particularly in non-participating states. There is an imperative need to include in the APRM process a group of elderly statesmen whose function would be timeous engagement with potentially troubled states to ameliorate tensions and incidences of underdevelopment. In Africa, elderly statesmen of such reputable functional diplomatic experience include former UN General Secretary Kofi Annan in Kenya, former South African President Thabo Mbeki in Zimbabwe, former Nigerian President Olusegun Obasanjo in the DRC, and former Mozambican President Joachim Chisano in Madagascar. Kuye and Kakumba (2008:156-168) call them "political ombuds". Therefore, it is submitted that there is an urgent need to restructure the current establishment of the APRM for purposes of promoting proactive political and economic intervention in potentially troubled African states. Such a restructured institution will be the African Peer Review Ombuds (APRO).

\section{Conclusion}

The concern in the article is the apparent denial of some African citizenry of basic tenet of democracy and good governance that should lead to reform of public services. It is the lack of these that is at the heart of mass uprising and revolt in some states The promotion of such reforms, it was argued, could stem such political upheavals and put African states on the road to development. The institution for stability promotion is the inspection agency of the African Union, the APRM.

African states and leaders have welcomed the African Peer Review Mechanism. The initiative holds much hope for promotion of political stability, economic growth and ultimate improved living standards. It is a worthwhile institution that can help promote and achieve the admonition by US President Barack Obama that "Africa does not need strong men. it needs strong institutions" (Pelser, 2009: 2).

\section{Bibliography}

Ashton C 2011. International reaction to Egyptian protests www.reuters.com/article2011/01/29 retrieved 2011/08/18

African Union (2004). African Union in a nutshell. Retrieved 24 July 2004 from www.africanunion.org

Agere S 2000. Promoting good government: Principles and perspectives. London: Management and Training Service Division of the Commonwealth Secretariat

APRM South Africa (2007). African Peer Review Mechanism. Retrieved 04 May 2007 from www.aprm.org.za

APRM (2009). Country reports. Retrieved 21 September 2009 from www.aprm-documents. 
Cohen M 2011. Ivory Coast Ouattara presidency claim opposed by army. www.businessweek.com/news/2010-12-11

Cole J. 2011. Tunisian uprising is a populist revolution www.democracynow.org/2011/1/18

Hanekom, SX. 1987. Public policy: Framework and instrument for action. Johannesburg: McMillan

Hope, K.R. (2005). Toward good governance and sustainable development: The African Peer Review Mechanism. Governance: An International Journal of Policy, Administration, and Institutions, 18(2). 285-299

Juma, M.K. (2004). Africa's governance audit: The African Peer Review Mechanism. New Economy, April.

Kanbur, R. (2004). The African Peer Review Mechanism (APRM): An assessment of concept and design. Politikon, 31(2) 152-166

Kuye, J.O. (2006). Public sector reforms: The case of South Africa - 1994-2005. Journal of Public Administration, 41(2.2) 286--299

Kuye, J.O. \& Kakumba, U. (2008). The Ombudsman institutions in the procurement of legal responsibilities in the Commonwealth: An overview of Canada, South Africa and Uganda. Journal of Public Administration 43(3.1). 156-168

Lamb K. 2011. Libya estimate at least 30000 die in civil war. San Francisco Chronicle Associated Press

Le Roux A 2009. Gaddafi dreaming of a United States of Africa. City Press, 8 February

Machel, G. (2009). Progress Report by Dr Graca Machel. Retrieved 21 September 2009 from www.aprm-documents

Maloka, E. (2004). NEPAD and its critics. Africa Insight, 34(4). 1-16

Maserumule MH. 2005. Good governance as a sine qua non for sustainable development in the New Partnership for Africa's Development 9NEPAD): a conceptual perspective Journal of Public Administration 40:3.1 (194-212)

Maru M. 2011. Gaddafi may cost AU -in terms of cash. City Press 10 July

Mutahaba, G. (2006). African perspectives on public service reform: Issues and performance. Journal of Public Administration, 41(2.2). 271-285

NEPAD, (2005). African Peer Review Mechanism. Retrieved 09 March 2007 from www.nepad.org/documents/49.pdf

Pelser, W. (2009). Africa's future is up to Africans. City Press, 12 July.

Rossouw M 2011. Libya: SA, AU U-turn driven by desire to reconstruct. City Press 25 September

Thomson, A..(2000). An introduction to African politics. London: Routledge.

Yuanfang P, Lei X \& Ka W. 2009. The conceptual transformation from government to governance and its representations: A case study on the innovations in city management of Ganzhou. http:/newurbanquestion.ifou.org/full papers/FO501 Accessed 20110831. 